\title{
A Novel Approach to Fabricate Foam Ceramics from Steel Slag
}

\author{
Yu Zheng $\mathbb{D}^{1},{ }^{1}$ Xudong Luo $\mathbb{D},{ }^{1}$ Jinlong Yang, ${ }^{2}$ Wenlong Huo, ${ }^{2}$ and Chi Kang ${ }^{1}$ \\ ${ }^{1}$ School of Materials and Metallurgy, Liaoning University of Science and Technology, Anshan, Liaoning 114051, China \\ ${ }^{2}$ State Key Laboratory of New Ceramics and Fine Processing, School of Materials Science and Engineering, Tsinghua University, \\ Beijing 100084, China \\ Correspondence should be addressed to Xudong Luo; luoxudongs@aliyun.com
}

Received 20 September 2019; Revised 25 February 2020; Accepted 2 March 2020; Published 26 March 2020

Academic Editor: Francesco Ruffino

Copyright (c) 2020 Yu Zheng et al. This is an open access article distributed under the Creative Commons Attribution License, which permits unrestricted use, distribution, and reproduction in any medium, provided the original work is properly cited.

\begin{abstract}
A novel approach is used for fabricating steel slag foam ceramics based on the particle-stabilized foaming method. In this work, steel slag was used as the raw material and propyl gallate (PG) was used as the surface modifier. For the first time, steel slag ceramic foams were successfully fabricated based on particle-stabilized foams. The results show that the stability of the ceramic foams was closely related to the $\mathrm{pH}$ value and PG concentration. The porosity and compressive strength could be controlled by changing the solid loading of steel slag and sintering temperature. The porosity of steel slag foam ceramics ranged from $85.6 \%$ to $62.53 \%$, and the compressive strength was from $1.74 \mathrm{MPa}$ to $10.42 \mathrm{MPa}$. The thermal conductivity of steel slag foam ceramics was only $0.067 \mathrm{~W}$ $(\mathrm{m} \cdot \mathrm{K})^{-1}$, which shows that it could be used as a thermal insulation material.
\end{abstract}

\section{Introduction}

Foam ceramics play an important role in high-technology fields and cellular structures composed of three-dimensional networks. The physical and chemical properties of foam ceramics can be adjusted by changing phase composition, the proportion of gas-solid phase, and the sintering temperature. Foam ceramics display low bulk density, excellent thermal conductive and acoustic insulation, high specific area, and excellent resistance [1]. Based on these properties, foam ceramics can be extensively applied in different fields, such as catalysis carriers, filtration material, biomaterials, thermal insulators, thermal barrier coatings, and soundproof materials [2-6]. Dickinson et al. [7] reported stabilized air bubbles prepared by direct foaming. Tang et al. [8] prepared well-defined porous ceramics with controllable pore size and porosity by burnout of fugitive pore formers. Wang et al. [9] and Deng et al. [10] prepared porous ceramics by particle stacking. Rainer et al. [11] reported the application of in situ foaming technique for the preparation of foam ceramics.

The direct foaming method is a simple and convenient route for the preparation of high-porosity ceramics with open or closed pores [12], by leading air in suspensions. As a promising direct foaming method, granular stabilized foam
[13-17] provides many advantages for the preparation foam ceramic materials, especially that there is no need to add organic or inorganic binders since the potential barrier assembled by ceramic particles has good gas-liquid interface stability.

With the development of industry, a large amount of industrial wastes not only pollute the environment but also occupy a large number of land. Many countries have realized that this phenomenon is an urgent problem to be solved. Steel slag is a by-product of steelmaking process and common industrial waste. In 2018, China's crude steel production was 928 million tons; however, the recycling rate was about $30 \%$. Therefore, this problem has attracted much attention during the past years and has been explored in many fields $[18,19]$. In the field of steel and metallurgy, steel slag can be used in metal recovery [20] and to prepare compound desulfurase [21]. In the field of construction, steel slag can be used as a cement raw meal [22-24] and subgrade backfill material [25]. In the field of agriculture, fertilizers [26] and soil improvers [12] can be prepared by using steel slag. In the field of environmental protection, steel slag can be used as raw materials to synthesize products which are applied in wastewater treatment [27]. 
In addition, glass ceramics can also be fabricated by using steel slag [1]. Some reports have carried out study on glass-ceramics $[24,25]$, including $\mathrm{CaSiO}_{3}, \mathrm{CaMgSi}_{2} \mathrm{O}_{6}$, and plagioclase systems $[12,26,27]$. However, there are few reports on the preparation of ceramics from steel slag. Thus, we propose a convenient, low-cost, and ecofriendly method to fabricate foam ceramic, which uses recycled steel slag powder as raw materials and is based on particle-stabilized foams theory $[28,29]$. Our work provides an effective approach to improve the utilization rate of steel slag and broadens the application field of solid waste resources. This is very beneficial to environmental protection and economy.

\section{Experimental Procedure}

2.1. Experimental Materials. The steel slag was provided by Chengde Iron and Steel Group Co., Ltd., Chengde, China. The element compositions of steel slag are listed in Table 1. Propyl gallate (PG) was purchased from Sinopharm Chemical Reagent Co. Ltd., Beijing, China.

2.2. Preparation of Steel Slag Foam Ceramics. Homogenization of aqueous steel slag suspensions was performed by ballmixing of aqueous suspensions consisting of deionized water and steel slag particles for $48 \mathrm{~h}$, and the steel slag has an average particle size of $1.62 \mu \mathrm{m}$. Figure 1 shows the SEM picture of steel slag after ball-mixing. PG (the addition amount was in terms of the total suspension quantity) was added to the suspensions, followed by ultrasonic dispersion for $5 \mathrm{~min}$ and tuning the $\mathrm{pH}$ value. The suspension was preliminarily agitated using a stirrer at the speed of $500 \mathrm{r} /$ min for $3 \mathrm{~min}$ and subsequently agitated at the speed of $1800 \mathrm{r} / \mathrm{min}$ for $10 \mathrm{minutes}$ to obtain uniform wet foams. The wet foams were dried at room temperature. The dried green body was sintered at $1150^{\circ} \mathrm{C}-1250^{\circ} \mathrm{C}$ with a heating rate of $3^{\circ} \mathrm{C} / \mathrm{min}$ and holding time of $2 \mathrm{~h}$. Figure 2 shows the preparation process of steel slag foam ceramics.

2.3. Characterization. The Archimedes method was employed to measure apparent porosity and bulk density of fired samples. Microstructures of the samples were characterized using scanning electron microscopy (SEM, MERLIN VP Compact, Carl Zeiss, Jena, Germany). Compressive strength of glass foams was measured with a crosshead speed of $1 \mathrm{~mm} / \mathrm{min}$ using a versatile material testing machine (AG2000G; Shimadzu, Kyoto, Japan). Three specimens were measured to obtain average values of bulk density and compressive strength. The grain size and pore size of steel slag foam ceramics were assessed by SEM images using "Nano Measurer" software (exploited by Fudan University, Shanghai, China). At least 300 pores and grains were counted to obtain average values and size distributions.

\section{Results and Discussion}

3.1. Fabrication of Stable Foam Steel Slag Suspension. The surface of ceramic powder particles was usually modified by using special organic water-soluble molecules. The water- soluble molecules adsorb on the surface of the oxide to reduce the particle's affinity for water molecules [30, 31]. Experiments show that PG can make steel slag powder hydrophobic and enable the attachment of steel slag particles to the air/water interfaces. Similar to most oxide ceramic powders, they generate hydroxyl groups on the surface of particles; steel slag particles allow the formation of hydroxyl groups due to the unsaturated bonds of oxygen atoms exposed on the surface of steel slag particles, providing a large number of anchoring groups for the adsorption of PG. Figure 3(a) shows the sample of steel slag foam slurry after demolding. The sample can keep its shape without adding auxiliary materials. After $48 \mathrm{~h}$ of sample preparation, there is a small amount of drainage from steel slag wet foams (Figure 3(b)). Steel slag particles are closely arranged on the gas/liquid interface due to van der Waals force, which forms the uniform stomatal wall, and the thickness is $1-1.5 \mu \mathrm{m}$ (Figure 3(c)). Figure 3(d) shows a process how the steel slag suspension develops into foams. After mechanical foaming, the liquid film separated the air in the suspension. Shortchain amphiphile PG is attached around the steel slag particles; the steel slag particles are closely aggregated at the air/liquid interfaces closely and form the dense particle layers around the bubbles to obtain stable wet foams. The foam loses water at normal temperature and pressure and eventually develops into dry foams. Steel slag particles pack at the air/liquid interfaces and form thin cell walls in the dried foams. At the same sintering temperature, the steel slag particles are densified and the pore structure remains spherical.

3.2. Influence of $P G$ and $p H$ on Stability of Steel Slag Foam Ceramics. A large number of experimental results demonstrate that the stability of steel slag foams depends on $\mathrm{pH}$ value and PG concentration, as shown in Figure 4. For particle-stabilized foam, $\mathrm{pH}$ is a key factor in determining the chemical state of the particle surface. It not only determines the adsorption behavior of the modifier on the particle surface but also determines the stability of the foam suspension. The stabilized foam is prepared in the range of pH 5.0 to $\mathrm{pH}$ 10.0. No matter how much PG is added, the wet steel slag foam cannot maintain long-term stability outside the $\mathrm{pH}$ range. The stability of wet foam mainly depends on the hydrophobicity of steel slag particles, which is mainly affected by the adsorption of the modifier (PG) on steel slag particles. The stability behavior with different $\mathrm{pH}$ values can be explained by the ligand exchange model [32]. When PG is dissolved in water, it first ionized by itself and then exchanged ligands with particles. The ionization of PG is greatly affected by the $\mathrm{pH}$ value, and the ionization degree of the PG increases as the $\mathrm{pH}$ value increases. The higher the degree of the pg ionization, the higher the degree of ligand exchange reaction. When the $\mathrm{pH}$ value is too low $(\mathrm{pH}<5.0)$, the degree of ionization of PG is low and the hydrophilicity is weak. The partial PG aggregated under the action of hydrophobization. PG is seriously inhibited, and a very small amount of PG can be adsorbed on the surface of steel slag particles. When the $\mathrm{pH}$ value is too high $(\mathrm{pH}>10.0)$, there 
TABLE 1: Composition of steel slag.

\begin{tabular}{lcccccccc}
\hline Composition & $\mathrm{CaO}$ & $\mathrm{SiO}_{2}$ & $\mathrm{Al}_{2} \mathrm{O}_{3}$ & $\mathrm{TiO}_{2}$ & $\mathrm{MgO}$ & $\mathrm{P}_{2} \mathrm{O}_{5}$ & $\mathrm{Fe}_{2} \mathrm{O}_{3}$ & $\mathrm{Na}_{2} \mathrm{O}$ \\
\hline Steel slag & 40.18 & 19.1 & 10.3 & 8.25 & 4.90 & 4.78 & 4.51 & 2.62 \\
\hline
\end{tabular}

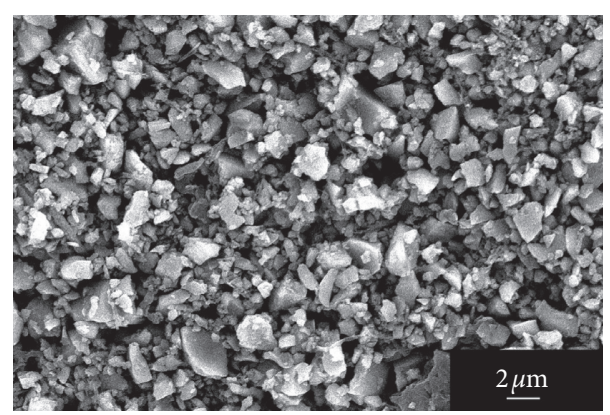

FIGURE 1: SEM images of steel slag particles after ball-mixing.

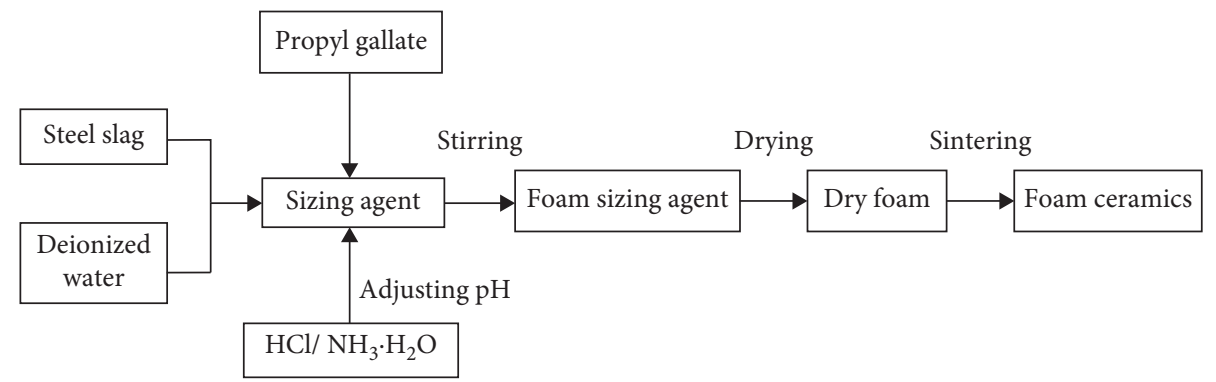

FIgURE 2: Preparation process of steel slag foam ceramics.

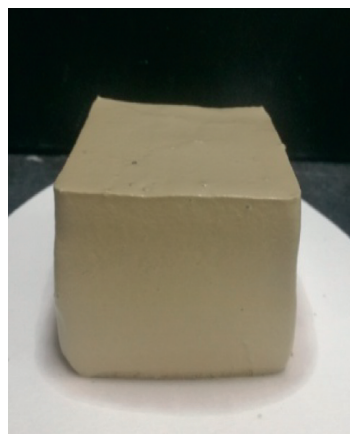

(a)

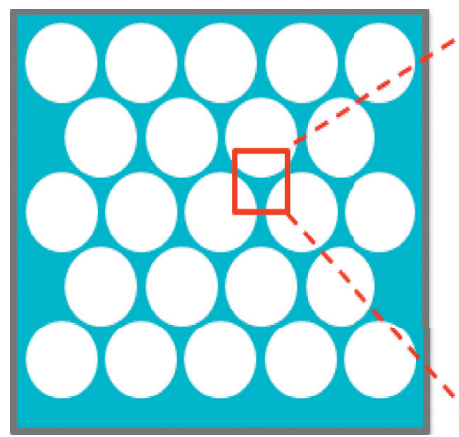

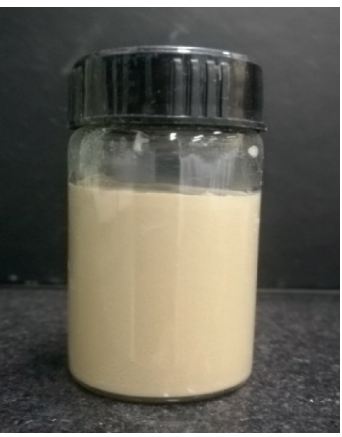

(b)

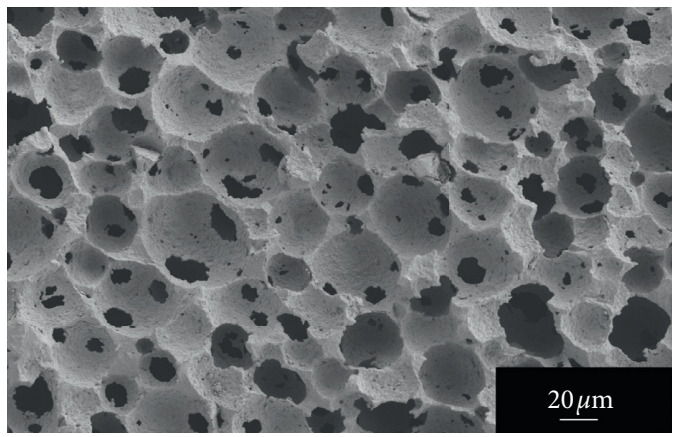

(c)

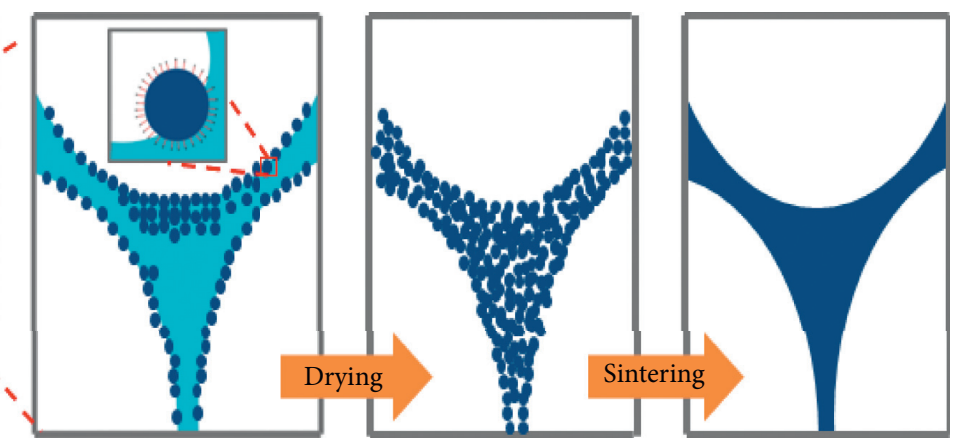

(d)

Figure 3: (a) Steel slag foam ceramics after demoulding. (b) Steel slag stabilized foams (the photo was taken $48 \mathrm{~h}$ after frothing). (c) Microstructure of steel slag foam ceramics. (d) Schematic diagram of ceramic foams with spherical pore structure. 


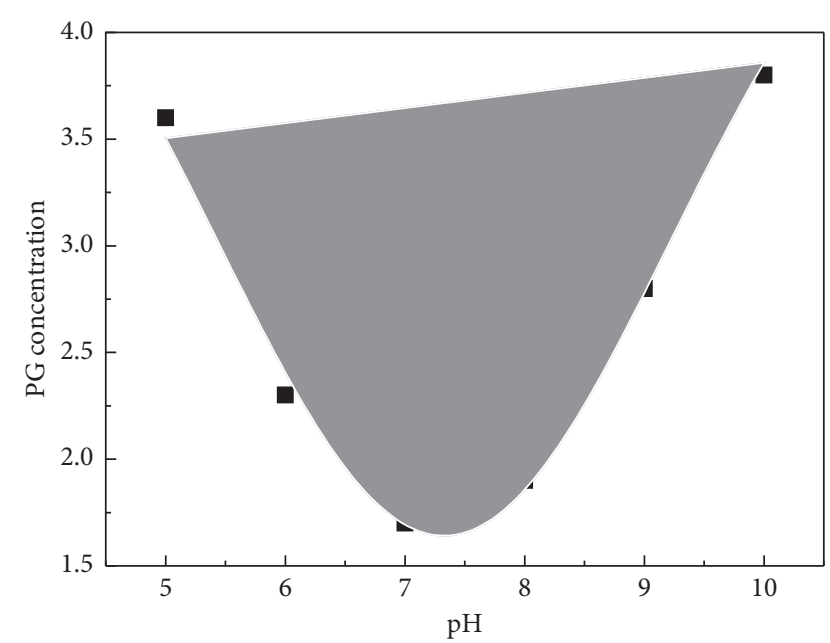

FIgUre 4: Dependence of foam stability on $\mathrm{pH}$ value and PG concentration (30 wt.\% solid loading).

are less available sites (namely, $-\mathrm{OH}_{2}^{+}$) for the adsorption of propyl gallate onto the steel slag surface since protonation of the particle surface is inhibited. In addition, at a high $\mathrm{pH}$ value, the negatively charged steel slag particles may be disadvantageous to deproton and PG adsorption due to electrostatic repulsion. Above all, if the $\mathrm{pH}$ value is lower than 5.0 or higher than 10.0, the adsorption of PG on steel slag particles is seriously inhibited, resulting in the inability of steel slag particles to achieve adequate hydrophobicity, leading to the instability of steel slag foams.

When the $\mathrm{pH}$ value is $5.0-10.0$, different PG concentrations are required to prepare stable wet steel slag foams. When $\mathrm{pH}$ ranges from 7.0 to 8.0, only a small amount of PG is needed to stabilize the wet foams of steel slag. When the $\mathrm{pH}$ range is $5-7$ or $8-10$, a relatively large amount of $\mathrm{PG}$ is needed to obtain the stable wet foam of steel slag, indicating that a large amount of PG can make up for the influence brought by the $\mathrm{pH}$ value.

\subsection{Influence of Solid Loading on the Properties of Steel Slag} Foam Ceramics. Solid loading is closely related to the stability of wet foam and the properties of foam ceramics. The experimental results show that when the solid content of steel slag is less than $20 \mathrm{wt} . \%$, the stable foamed ceramics cannot be prepared. The previous literature has suggested that to ensure the stability of foam suspensions, particles should be covered at the air/liquid interface [33]. With the increase of steel slag solid loading, the porosity of foam ceramics decreases from $85.6 \%$ to $68.4 \%$ and the compressive strength increases from $1.74 \mathrm{MPa}$ to $2.93 \mathrm{MPa}$ (Figure 5). Low solid loading leads to low viscosity of suspension, which is conducive to the incorporation of more air into the ceramic slurry during agitation [34, 35]. Therefore, as the solid content of the steel slag increases, the porosity of foam ceramics decreases and the compressive strength increases, which can be explained by the model of Gibson and Ashby [36]. The porosity and compressive strength of steel slag foams prepared with $30 \mathrm{wt} . \%$ of the

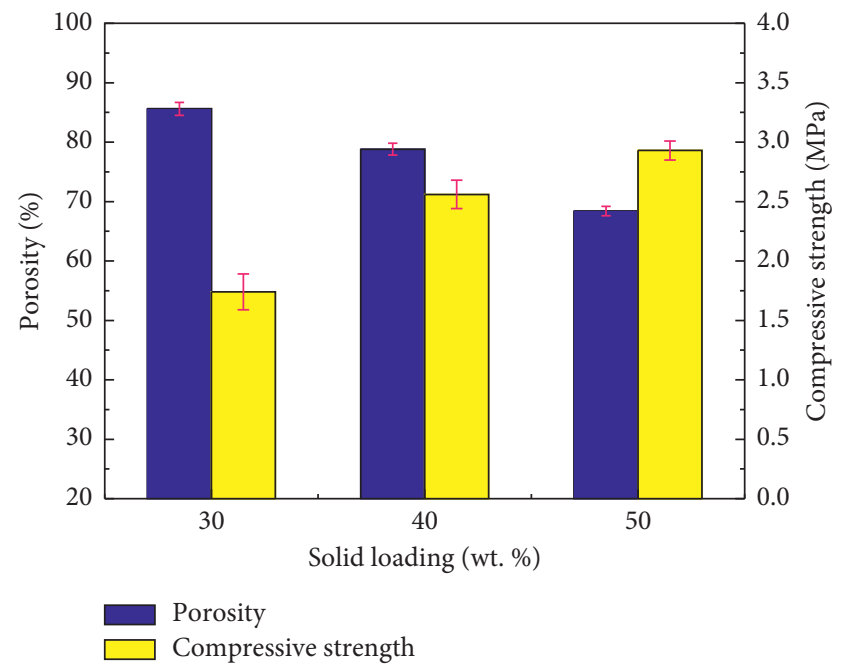

FIGURE 5: Effect of solid loading on properties of steel slag foam ceramics.

solid loading are, respectively, $85 \pm 1.1 \%$ and $1.74 \pm 0.15 \mathrm{MPa}$. The strength of steel slag foam ceramics can be employed in some fields.

3.4. Influence of Sintering Temperature on the Properties of Steel Slag Foam Ceramics. The SEM images of steel slag foam ceramics sintered at different temperatures are shown in Figure 6. At $1150^{\circ} \mathrm{C}$, the porosity diameter of foam ceramics is larger than $1200^{\circ} \mathrm{C}$ and $1250^{\circ} \mathrm{C}$ due to insufficient sintering densification. With the increase in sintering temperature, the sintered steel slag ceramic foams exhibit well distribution as shown in Figures 6(b) and 6(c). When the sintering temperature reaches $1250^{\circ} \mathrm{C}$, the multistage pore structure is stable and the pores are highly connected, which is conducive to thermal insulation performance.

The porosity of steel slag ceramic foams sintered at different temperatures is shown in Figure 7. As shown in Figure 7, the porosity of steel slag foam ceramics at different sintering temperatures decreases with the increase in temperature, which is similar to previous results [29]. This can be explained by the grain growth with the increase in sintering temperature, accompanying with the thickening of wall and decrease in pore size. In addition, it is noted that the porosity of ceramic foam of steel slag decreased more significantly (from $84.86 \%$ to $52.17 \%$ with increasing sintering temperature from $1150^{\circ} \mathrm{C}$ to $1200^{\circ} \mathrm{C}$ ) when compared to that at sintering temperature from $1200^{\circ} \mathrm{C}$ to $1250^{\circ} \mathrm{C}$ (from $52.17 \%$ to $46.12 \%)$.

As sintering temperature increases, the porosity decreases accompanied by the increase in the compressive strength. More shrinkage occurs at higher sintering temperature. Therefore, the strut wall prepared at higher sintering temperature is thicker [37]. The thickening has a positive effect on the compressive strength but results in lower porosity. Compressive strength increased from $2.56 \pm 0.06 \mathrm{MPa}$ to $10.42 \pm 0.09 \mathrm{MPa}$ when the sintering 


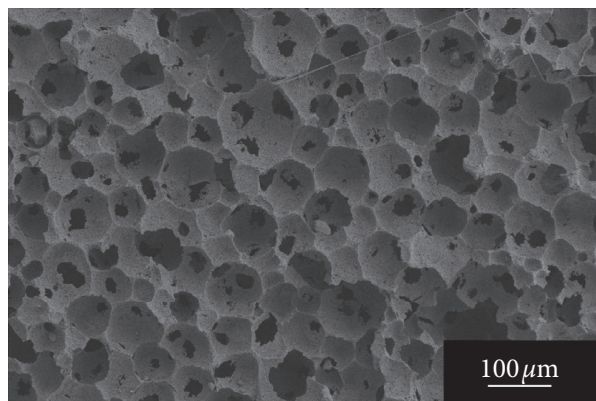

(a)

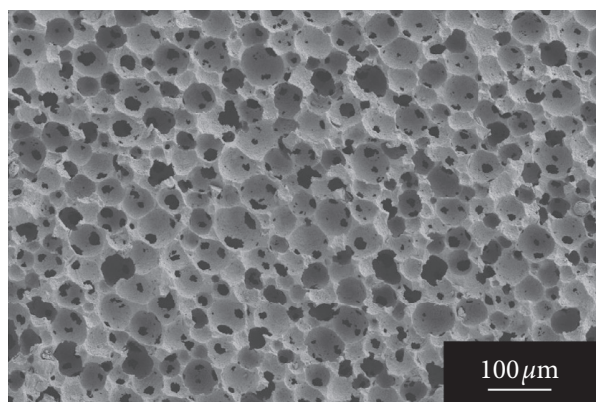

(c)

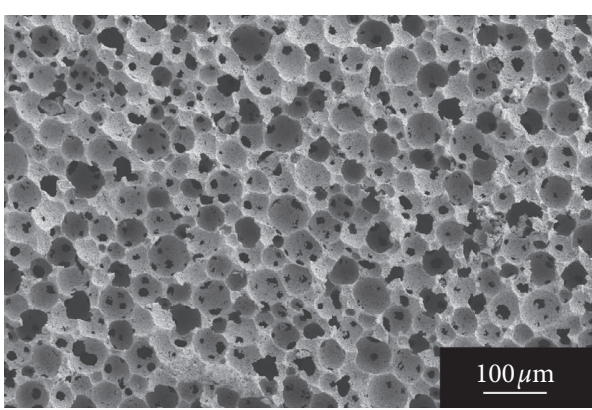

(b)

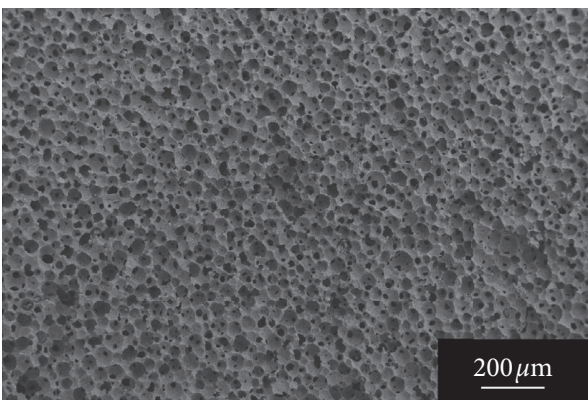

(d)

FIGURE 6: SEM images of cell wall of steel slag foams fabricated with $40 \mathrm{wt} . \%$ solid loading sintered at (a) 1150 , (b) $1200^{\circ} \mathrm{C}$, and at (c) (d) $1250^{\circ} \mathrm{C}$.

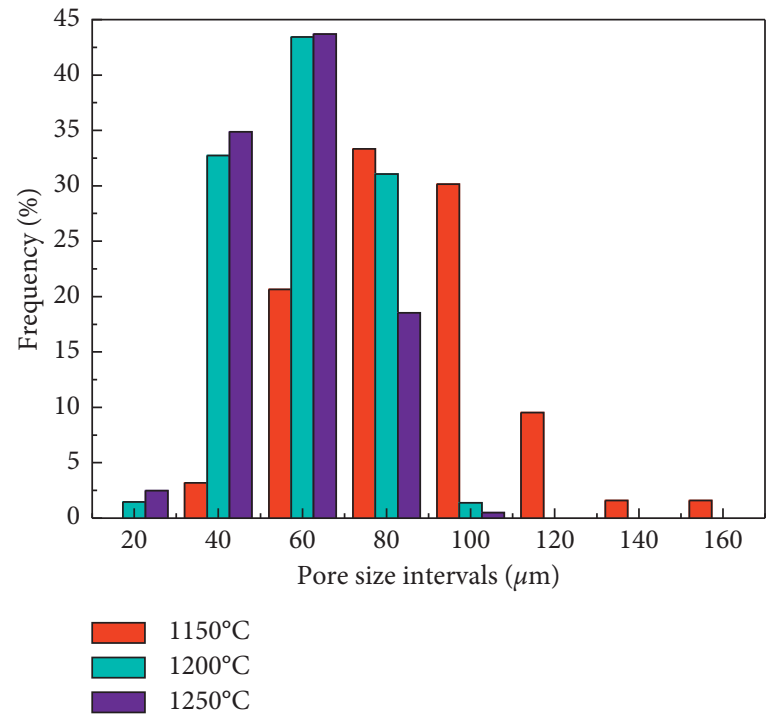

(a)

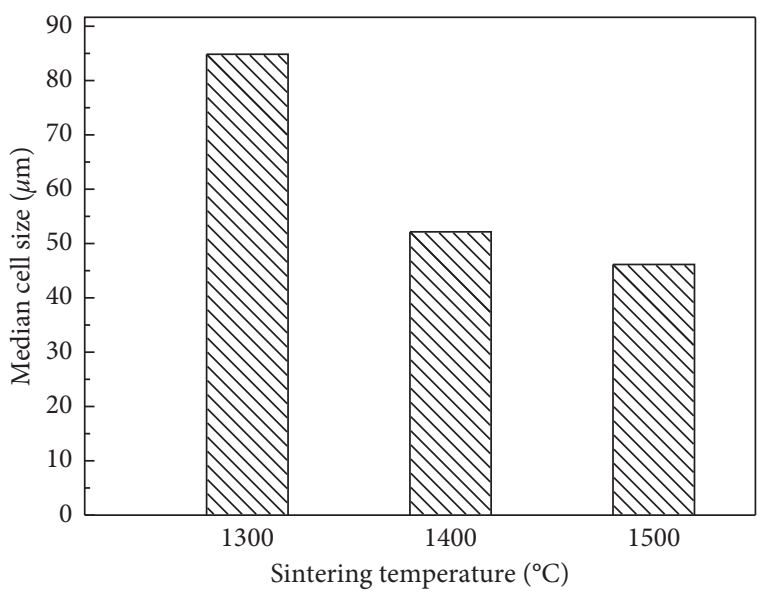

(b)

Figure 7: Pore size distribution of steel slag foam ceramics sintered at $1150^{\circ} \mathrm{C}, 1200^{\circ} \mathrm{C}$, and $1250^{\circ} \mathrm{C}$ (a) and mean pore size of steel slag foam ceramics sintered at different temperatures (b) (40 wt.\% solid loading).

TABle 2: Porosity and compressive strength as a function of sintering temperature (prepared from $40 \mathrm{wt} \%$ solid loading.

\begin{tabular}{lcc}
\hline $\begin{array}{l}\text { Sintering } \\
\text { temperature }\left({ }^{\circ} \mathrm{C}\right)\end{array}$ & $\begin{array}{c}\text { Porosity } \\
(\%)\end{array}$ & \begin{tabular}{c} 
Compressive strength $(\mathrm{MPa})$ \\
\hline 1150
\end{tabular} \\
1200 & $70.78 \pm 0.04$ & $2.56 \pm 0.06$ \\
1250 & $62.53 \pm 0.06$ & $9.08 \pm 0.03$ \\
\hline
\end{tabular}

temperature increased from $1150^{\circ} \mathrm{C}$ to $1250^{\circ} \mathrm{C}$, along with decrease in porosity from $84.78 \%$ to $62.53 \%$ (Table 2 ).

It is reported that the thermal conductivity of most foam ceramics approaches a lower limit of $0.1 \mathrm{~W}(\mathrm{~m} \cdot \mathrm{K})^{-1}$ [38]. It is fascinating to note that thermal conductivity of steel slag foams with a porosity of $85.6 \%$ is $0.067 \mathrm{~W}(\mathrm{~m} \mathrm{~K})^{-1}$, which is lower than that of most foam ceramics. Therefore, steel slag 
foam ceramics can be used to prepare thermal insulation materials.

\section{Conclusion}

Steel slag foam ceramics are prepared by the particle-stabilized direct foaming method. The hydrophobicity of steel slag particles is improved by in situ adsorption of PG. The steel slag foams show strong foam ability and stability. It is a facile and low-cost method to fabricate steel slag foams with porosity in the range of $85.6 \%-62.53 \%$ and with high compressive strength in the range of 1.74-10.42 $\mathrm{MPa}$. The steel slag foams with high porosity and low thermal conductivity could be applied in thermal insulation and other potential fields.

\section{Data Availability}

The data generated and analyzed in this manuscript are available from the corresponding author on reasonable request.

\section{Conflicts of Interest}

The authors declare that they have no conflicts of interest.

\section{Acknowledgments}

This work was financially supported by the National Natural Science Foundation of China (Grant no. 51772139).

\section{References}

[1] P. Colombo, "Conventional and novel processing methods for cellular ceramics," Philosophical Transactions of the Royal Society A: Mathematical, Physical and Engineering Sciences, vol. 364, no. 1838, pp. 109-124, 2006.

[2] C. Chuanuwatanakul, C. Tallon, D. E. Dunstan, and G. V. Franks, "Controlling the microstructure of ceramic particle stabilized foams: influence of contact angle and particle aggregation," Soft Matter, vol. 7, no. 24, pp. 1146411467, 2011.

[3] W.-L. Huo, F. Qi, X.-Y. Zhang et al., "Ultralight alumina ceramic foams with single-grain wall using sodium dodecyl sulfate as long-chain surfactant," Journal of the European Ceramic Society, vol. 36, no. 16, pp. 4163-4170, 2016.

[4] J. Wang, A. V. Nguyen, and S. Farrokhpay, "A critical review of the growth, drainage and collapse of foams," Advances in Colloid and Interface Science, vol. 228, pp. 55-70, 2016.

[5] J. Yu, J. Yang, H. Li, X. Xi, and Y. Huang, "Study on particlestabilized Si3N4 ceramic foams," Materials Letters, vol. 65, no. 12, pp. 1801-1804, 2011.

[6] R. Ahmad, J.-H. Ha, and I.-H. Song, "Fabrication of selfsetting $\mathrm{Al}(\mathrm{OH})_{3}$ foams for potential fire-retarding applications," Materials Letters, vol. 139, pp. 252-254, 2015.

[7] E. Dickinson, R. Ettelaie, T. Kostakis, and B. S. Murray, "Factors controlling the formation and stability of air bubbles stabilized by partially hydrophobic silica nanoparticles," Langmuir, vol. 20, no. 20, pp. 8517-8525, 2004.

[8] F. Tang, H. Fudouzi, T. Uchikoshi, and Y. Sakka, "Preparation of porous materials with controlled pore size and porosity,"
Journal of the European Ceramic Society, vol. 24, no. 2, pp. 341-344, 2004.

[9] F. Wang, J. Ye, G. He, G. Liu, Z. Xie, and J. Li, "Preparation and characterization of porous $\mathrm{MgAl}_{2} \mathrm{O}_{4}$ spinel ceramic supports from bauxite and magnesite," Ceramics International, vol. 41, no. 6, pp. 7374-7380, 2015.

[10] Z.-Y. Deng, J.-F. Yang, Y. Beppu, M. Ando, and T. Ohji, "Effect of agglomeration on mechanical properties of porous zirconia fabricated by partial sintering," Journal of the American Ceramic Society, vol. 85, no. 8, pp. 1961-1965, 2002.

[11] A. Rainer, F. Basoli, S. Licoccia, and E. Traversa, "Foaming of filled polyurethanes for fabrication of porous anode supports for intermediate temperature-solid oxide fuel cells," Journal of the American Ceramic Society, vol. 89, no. 6, pp. 1795-1800, 2006.

[12] M. Scheffler and P. Colombo, Cellular Ceramics: Structure, Manufacturing, Properties and Applications, John Wiley \& Sons, Weinheim, Germany, 2006.

[13] B. P. Binks, "Particles as surfactants-similarities and differences," Current Opinion in Colloid \& Interface Science, vol. 7, no. 1-2, pp. 21-41, 2002.

[14] U. T. Gonzenbach, A. R. Studart, E. Tervoort, and L. J. Gauckler, "Ultrastable particle-stabilized foams," Angewandte Chemie International Edition, vol. 45, no. 21, pp. 3526-3530, 2006.

[15] U. T. Gonzenbach, A. R. Studart, E. Tervoort, and L. J. Gauckler, "Macroporous ceramics from particle-stabilized wet foams," Journal of the American Ceramic Society, vol. 90, no. 1, pp. 16-22, 2007.

[16] W. Huo, Y. Chen, Z. Zhang et al., "Highly porous barium strontium titanate (BST) ceramic foams with low dielectric constant from particle-stabilized foams," Journal of the American Ceramic Society, vol. 101, no. 4, pp. 1737-1746, 2018.

[17] W. Huo, S. Yan, J.-M. Wu et al., “A novel fabrication method for glass foams with small pore size and controllable pore structure," Journal of the American Ceramic Society, vol. 100, no. 12, pp. 5502-5511, 2017.

[18] S. K. Das, S. Kumar, and P. Ramachandrarao, "Exploitation of iron ore tailing for the development of ceramic tiles," Waste Management, vol. 20, no. 8, pp. 725-729, 2000.

[19] B. C. Chukwudi, P. O. Ademusuru, and B. A. Okorie, "Characterization of sintered ceramic tiles produced from steel slag," Journal of Minerals and Materials Characterization and Engineering, vol. 11, no. 9, pp. 863-868, 2012.

[20] B. Das, S. Prakash, P. S. R. Reddy, and V. N. Misra, "An overview of utilization of slag and sludge from steel industries," Resources, Conservation and Recycling, vol. 50, no. 1, pp. 40-57, 2007.

[21] T. Dong, Z. D. Tao, and C. Qing, "Study on using steel slag as a raw meal component for cement clinker," in Proceedings of the 2011 International Conference on Materials for Renewable Energy \& Environmen(ICMREE), pp. 1193-1196, Shanghai, China, May 2011.

[22] C. H. Feng and D. X. Li, "Effects of steel slag used as iron corrective raw material on the properties of cement clinker," Journal of the Chinese Ceramic Society, vol. 38, no. 9, pp. 1688-1692, 2010.

[23] H. Ş. Soykan, "Cementitious material production from hot mixing of ironmaking and steelmaking slags," Mineral Processing and Extractive Metallurgy, vol. 115, no. 4, pp. 229-233, 2006. 
[24] H. Y. Poh, G. S. Ghataora, and N. Ghazireh, "Soil stabilization using basic oxygen steel slag fines," Journal of Materials in Civil Engineering, vol. 18, no. 2, pp. 229-240, 2006.

[25] P. E. Tsakiridis, G. D. Papadimitriou, S. Tsivilis, and C. Koroneos, "Utilization of steel slag for Portland cement clinker production," Journal of Hazardous Materials, vol. 152, no. 2, pp. 805-811, 2008.

[26] H. Yi, G. Xu, H. Cheng, J. Wang, Y. Wan, and H. Chen, “An overview of utilization of steel slag," Procedia Environmental Sciences, vol. 16, pp. 791-801, 2012.

[27] T. Ohji and M. Fukushima, "Macro-porous ceramics: processing and properties," International Materials Reviews, vol. 57, no. 2, pp. 115-131, 2012.

[28] U. T. Gonzenbach, A. R. Studart, E. Tervoort, and L. J. Gauckler, "Stabilization of foams with inorganic colloidal particles," Langmuir, vol. 22, no. 26, pp. 10983-10988, 2006.

[29] U. T. Gonzenbach, A. R. Studart, D. Steinlin, E. Tervoort, and L. J. Gauckler, "Processing of particle-stabilized wet foams into porous ceramics," Journal of the American Ceramic Society, vol. 90, no. 11, pp. 3407-3414, 2007.

[30] B. P. Binks and T. S. Horozov, "Aqueous foams stabilized solely by silica nanoparticles," Angewandte Chemie International Edition, vol. 44, no. 24, pp. 3722-3725, 2005.

[31] S. Ata, "Coalescence of bubbles covered by particles," Langmuir, vol. 24, no. 12, pp. 6085-6091, 2008

[32] J. O. Leckie, Adsorption and Transformation of Trace Element Species at Sediment/water Interfaces, Springer, Berlin Heidelberg, 1986.

[33] G. Kaptay, "Interfacial criteria for stabilization of liquid foams by solid particles," Colloids and Surfaces A: Physicochemical and Engineering Aspects, vol. 230, no. 1-3, pp. 67-80, 2003.

[34] I. Lesov, S. Tcholakova, M. Kovadjieva, T. Saison, M. Lamblet, and N. Denkov, "Role of pickering stabilization and bulk gelation for the preparation and properties of solid silica foams," Journal of Colloid and Interface Science, vol. 504, pp. 48-57, 2017.

[35] I. Lesov, S. Tcholakova, and N. Denkov, "Factors controlling the formation and stability of foams used as precursors of porous materials," Journal of Colloid and Interface Science, vol. 426, pp. 9-21, 2014.

[36] L. J. Gibson and M. F. Ashby, Cellular Solids: Structure and Properties, Cambridge University Press, Cambridge, UK, 2nd edition, 1997.

[37] A. Rizwan, J. H. Ha, and I. H. Song, "Effect of valeric acid on the agglomeration of zirconia particles and effects of the sintering temperature on the strut wall thickness of particlestabilized foam," Journal of the European Ceramic Society, vol. 34, no. 5, pp. 1303-1310, 2014.

[38] B. Nait-Ali, K. Haberko, H. Vesteghem, J. Absi, and D. S. Smith, "Thermal conductivity of highly porous zirconia," Journal of the European Ceramic Society, vol. 26, no. 16, pp. 3567-3574, 2006. 